\title{
Chapter 6 \\ European Cities in Search of Knowledge for Their Integration Policies
}

\author{
Rinus Penninx
}

\subsection{Introduction}

In the study of integration policies, the national level of individual countries has been the dominant unit of analysis. In such studies, integration policies towards newcomers are studied under the assumption that such a national frame sets conditions for processes of integration everywhere in the country and at all levels. There is an abundance of such national studies, often funded by policy agencies. There is also an established tradition of comparative studies of countries and their integration models, ${ }^{1}$ including a critical stream of studies on such 'national models' (see also Chap. 4). ${ }^{2}$

Studies of integration processes and policies at the lower levels of cities and municipalities are more recent than national ones. A quick inventory of the international literature reveals that such studies appeared already well before the turn of the century. Early studies focused predominantly on the political dimension of integration and policies related to civic and political participation, as in the case of Patrick Ireland's study of four cities in France and Switzerland (Ireland 1994); Rex and Samad (1996) on Birmingham and Bradford; Blommaert and Martiniello (1996) on Antwerp and Liège; Garbaye (2000) on Birmingham and Lille; Bousetta

\footnotetext{
${ }^{1}$ For an overview of European studies, see Penninx et al. 2006. For a recent overview of policymaking (in ten European countries) see Zincone et al. 2011.

${ }^{2}$ See for example Favell 1998; Bommes and Morawska 2005; Thränhardt and Bommes 2010; Entzinger and Scholten 2014.

R. Penninx $(\square)$

Institute for Migration and Ethnic Studies, University of Amsterdam, Nieuwe Achtergracht 166, 1018 WV Amsterdam, Netherlands

e-mail: m.j.a.penninx@uva.nl
} 
(2001) on Antwerp, Liège, Lille and Utrecht and Fennema and Tillie (2004) on Amsterdam, Liège and Zürich. Other studies focused on specific aspects of local policies such as housing and segregation patterns in nine cities (Musterd et al. 1998), policing in Paris, Marseille and Lyon as compared to New York and Chicago (Body-Gendrot 2000), local policies relating to Islam and Muslim institutions in European cities (Rath et al. 2001; Maussen 2009) or the management of diversity in the implementation of local policies in Manchester and Marseille (Moore 2001, 2004). More recently we also saw examples of attempts to compare the making of local integration policies (Caponio and Borkert 2010; Gesemann and Roth 2009).

An early large-scale comparative analysis of integration policies at the local level of cities has been done in the MPMC-project (Multicultural Policies and Modes of Citizenship in European Cities). The MPMC-project ran from 1996 till 2004. It focused in its empirical research particularly on the political participation of immigrants, but that specific focus was framed in a more general comparison of cities, their immigrants and local governmental policies. Systematic descriptions were made of 16 major European cities and Tel Aviv. ${ }^{3}$ In two book publications (Rogers and Tillie 2001; Penninx et al. 2004) general comparisons of policies and cities were supplemented by in-depth comparisons on selected topics. Alexander (2004) used this material not only to construct a first typology of local policies, but also to devise a new in-depth comparison of policies in Amsterdam, Paris, Rome and Tel Aviv (Alexander 2003, 2007).

There is thus an increasing scientific literature on local integration policies, but does this literature inform us about the existence of research-policy structures and dialogues at the local level? Are local policymakers searching for knowledge and/or are researchers providing knowledge relevant for policies? The literature mentioned above is not commissioned and funded by cities or local policymakers, so not part of a research-policy dialogue. But there is also a less well known (and difficult to find) subset of local research on migrant policies. It is this local policy-research nexus that I would like to explore in this contribution.

In the exploration below, I will try to systematise evidence from personal observations as a researcher and policymaker in the Netherlands, ${ }^{4}$ from research institutes within the IMISCOE-consortium, from my participation as a researcher in research projects on local integration policies, such as the MPMC-project and the CLIP-project (Cities for Local Integration: see below), and from advising cities on their policies. In the course of this exploration, I will make some observations

\footnotetext{
${ }^{3}$ The city templates are available on the UNESCO website: www.unesco.org/most

${ }^{4}$ The author worked in Dutch ministries responsible for (stimulating local) integration policies from 1978 till 1988. He was director of the Institute for Migration and Ethnic Studies at the University of Amsterdam from 1992 to 2006. He was co-chair of the International Metropolis-project from 1999 till 2009. He was coordinator of IMISCOE - a European network of research institutes in the field of migration and integration - from its inception in 2004 until 2014. In all these capacities he has been involved in policy-research dialogues, including those at the local level in Dutch cities (Amsterdam and Haarlem) and through the CLIP-project in Copenhagen (Denmark) and Turku (Finland). See: Penninx 1988, 2005a, b, 2009; Penninx et al. 2004; Wolff et al. 1999.
} 
on how cities define their needs and possibilities to acquire knowledge that they perceive as relevant. The special position of local authorities in the multi-level governance of migration and integration (i.e. their relations with national and European Union policies) receives special attention, since this influences their possibilities to collect certain knowledge. I will also outline a number of initiatives led by cities for horizontal exchange of relevant knowledge on good or best practices that have sprung up during the last decade. Finally, I will make some tentative concluding remarks on the policy-research-nexus on the local level.

\subsection{Dutch Cities in the Quest to Acquire Knowledge About Migrant Integration}

In 1986, the Advisory Committee Research on Minorities in the Netherlands (ACOM) published a 'Review of Municipal Minorities Research': a survey of some 100 research projects initiated by 54 municipalities in the Netherlands, not including the four major cities Amsterdam, Rotterdam, The Hague and Utrecht (Uniken Venema 1986). More than $80 \%$ of these municipalities had been engaged in research or were doing so at that time. The four largest cities had built up significant research programmes by then (Uniken Venema 1986: i). The report notes that the decisions to have research done were mostly taken by either researchers or policymakers working for the city who wanted policy-relevant data or information. The research was often implemented by municipal research or statistical departments. Most of it was small in scale.

The significant engagement of Dutch cities and municipalities in research and data collection about migrants in their cities should be understood against the background of a new national policy: the national government had decided in 1980 to have an Ethnic Minorities Policy for the integration of immigrant groups in the Netherlands (Ministerie van Binnenlandse Zaken 1980). One of the starting points of that new policy was that cities and local authorities should develop an active local integration policy for immigrants and minorities. To stimulate local authorities to do so a special temporary regulation was made to finance extra costs for setting up local policies (the 'Extra Bestuurskosten Regeling'), starting in 1980. One of these extra costs mentioned explicitly was research for policy. Local authorities thus received funding from the national government that they could use to have research done. Obviously this funding facility was readily used. This was confirmed in an analysis of research projects on minorities in the Netherlands in the period 1981-1985: the percentage of research projects financed by cities/municipalities had increased from $6 \%$ in 1981 to $25 \%$ in 1984 (Penninx 1988: 13).

Admittedly, such a stimulating environment for research initiatives at the local level was exceptional in Europe in the 1980s: the Netherlands was one of the few countries that developed a national integration policy quite early (i.e. before the turn of the century). The other country that had an integration policy (still earlier, 
since 1975 ) was Sweden. ${ }^{5}$ Probably there was also an early local Policy-Research Nexus in Sweden, although one of the few reviews of policy-research connections in Sweden that covers the period between 1965 and 1984 (Hammar 2004) does not mention cities as initiators or users of research. For the later period, after 1984, there is more evidence that Swedish cities - particularly Stockholm, Göteborg and Malmö ${ }^{6}$ - have initiated and co-financed research from universities in their cities on a significant scale and developed contacts with the universities in their cities on issues of local integration policies.

What function did research on the local level in the Netherlands have for policymakers and what function did that research have in the policy cycle? In view of the specific context, local research projects in the Netherlands were not initiated as tools for recognition and problem definition in the first phase of such a cycle. Instead, recognition and problem definition were attributable to the (national) context and policy. Local research projects had much more of a function for the second phase - that of supporting the concrete instrumentation of policies. Such research was supposed to answer questions about what issues policymakers should prioritise and what instruments could be used. Later, when local policy was in place, the attention shifted to the third phase of the cycle: evaluation. Monitoring outcomes of policy and evaluation of policies became central issues in research. As to monitoring, cities chose predominantly two forms: the first were self-evaluative monitoring systems to be filled in by practitioners themselves. (Sometimes such systems were designed with external help from researchers.) The second is that the statistical services of the city were asked to produce data regularly and in a systematic way.

Cities, particularly larger cities that built up a longstanding tradition of integration policies such as Amsterdam and Rotterdam in the Netherlands, did commission part of their research to external researchers: to universities but also to commercial research institutes. In the case of Amsterdam, for example, the Institute for Migration and Ethnic Studies (IMES) at the University of Amsterdam was commissioned regularly since its inception in 1992 by the city to do evaluation studies, often on a specific part of their policies or a specific strategy. IMES evaluated e.g. the specific strategy of one of the districts of Amsterdam to engage organisations of immigrants in policymaking and implementation in the district (Wolff et al. 1999), and more recently did a study about radicalisation of Muslims in Amsterdam (Slootman and Tillie 2006). In Rotterdam, the Citizenship, Migration and the City (CIMIC) programme of the Faculty of Social Sciences has more recently developed

\footnotetext{
${ }^{5}$ One could argue that also the UK had early integration policies since the mid-1960s, but these policies focused primarily on 'race relations' and did not go under the label of 'integration'.

${ }^{6}$ The city of Malmö is closely connected to the emergence of the MIM-department (Malmö Institute for Studies of Migration, Diversity and Welfare) at Malmö University. The city has financed among other things the Guest Professorship in International Migration and Ethnic Relations in Memory of Willy Brandt since 1998.
} 
regular contacts between the Erasmus University and the city, which includes commissioning research by the city of Rotterdam. ${ }^{7}$

In the fourth phase of the policy cycle, local politicians and policymakers also regularly felt the need to reformulate policies. That need could be based primarily on monitoring and evaluation, but was often also inspired primarily by a need for a political redefinition of the field. Researchers were often asked to participate in commissions to advise politicians and policymakers on this. For example, I participated in an expert commission (Commissie van Deskundigen 1998) that advised the city of Amsterdam on the revision of their minorities policy in 1998.

As regards the question of how cities use knowledge, and what kind of knowledge, the material suggests that they use research and knowledge primarily for the instrumentation of their policies. In the course of time cities have formulated their specific needs more and more in terms of 'exchange of policy practice', often called good or best practices. Initiatives for such international exchange and learning between cities had already started in the Netherlands by the 1990s. For example, in 1998 the city of Amsterdam and its local district mayors invited policymakers and practitioners from Antwerp, Berlin, Birmingham, Brussels, Copenhagen, Frankfurt am Main, Liège, London, Manchester, Madrid, Milan, Rotterdam, Stockholm, Utrecht and Vienna for the Ethnic Minorities and Local Government Conference (Bestuurlijk Overleg Stadsdelen 1998). The conference itself also illustrates a form of research-policy dialogue on the local level: the city organisers hired researchers to prepare the conference and several of the invited cities brought their own scientific advisors to the conference (Amsterdam, Liège, London, Manchester, Rotterdam and Stockholm).

The city of Amsterdam conference in 1998 was not exceptional in the Netherlands: the city of Haarlem, for example, organised a conference in 2004 with its twin cities Osnabrück (Germany) and Angers (France) comparing the integration policies of the three cities. A comparative report was commissioned from the Institute for Migration and Ethnic Studies of the University of Amsterdam (Penninx 2005b). When doing the comparative study, it turned out that the city of Osnabrück had commissioned studies from the Institute for Migration and Intercultural Studies (IMIS) at the University of Osnabrück in 1998 and 2000 (by Michael Bommes and others) to revise its policies. ${ }^{8}$

\footnotetext{
${ }^{7}$ The city's interest in research is also expressed in the fact that the city co-financed in the past a special chair on Islam and recently supported the transition of the coordination of IMISCOE to the Erasmus University of Rotterdam.

${ }^{8}$ The first 1998 report led to new integration policies in the city of Osnabrück in 1999, very much inspired by Dutch local integration policies. In a second report of 2000, IMIS reported on the feasibility of concrete policies in five areas.
} 


\subsection{European Cities and Their National Connections}

Local integration policies have always been in the shadow of national integration policies or in the shadow of the absence of the latter, first of all because immigration policies (decisions about who is allowed to enter and stay) are made at the national level. If immigration policy is followed by a national integration policy, as happened in an early phase in Sweden (since 1975) and the Netherlands (since 1980), then local integration policies are stimulated and facilitated by such national policies. That is why Dutch and Swedish cities do have a longer history of local integration policies than other European cities. By implication, they also have developed forms of local research-policy dialogues, as described above for Dutch cities.

But immigration in Europe in the second half of the twentieth century was not necessarily followed by integration policy at the national level: most West European countries experienced significant immigration but did not enact national integration policies until the turn of the century. Nevertheless, immigrants did settle in cities and municipalities and some of these cities (but by no means all!) did develop integration policies, also in the absence of national policies. Quite a few of the cities that Amsterdam had invited to its conference in 1998 (the ones not coming from the Netherlands, Sweden and the UK) were cities that had pioneered local integration policies without the support of their national authorities.

Similarly, cooperation between universities and cities on research and integration policies, such as we mentioned for the Dutch case, was not exceptional in the late 1990s in Europe. When I was preparing the IMISCOE Network of Excellence in 2003, most of the 19 research institutes that were part of the IMISCOE-project in the beginning had undertaken a significant number of research projects commissioned by cities and local authorities. This was clearly the case for IMES (University of Amsterdam), CEDEM (University of Liège, Belgium), CEIFO (University of Stockholm, Sweden), COMPAS (University of Oxford, United Kingdom), efms (University of Bamberg, Germany), IMIS (University of Osnabrück, Germany), the Austrian Academy of Sciences (in Vienna, Austria) and FIERI (in Torino, Italy). ${ }^{9}$

Swiss cities are interesting cases to illustrate how cities have developed local integration policies in a national context with a long history of temporary employment of foreign workers in which the concept of integration was non-existent (D'Amato and Gerber 2005; Wicker 2003). In the second half of the 1990s, anthropologists (ethnologists) at universities in the cities of Zurich, Bern and Basel conducted research on the integration of immigrants and - in collaboration with city authorities - developed so called 'Integrationsleitbilder' (integration policy frames: Begert 2005; Kessler 2005; Tremp 2005). Contrary to what I described for cities in the Netherlands, this input of researchers did function as the first phase of a policy cycle, that of recognition and problem definition. At the same time

\footnotetext{
${ }^{9}$ It is not accidental that five of these institutes formed the consortium that would provide CLIPcities with the case-study research and the comparative reports of their policies between 2006 and 2012.
} 
the cities cooperated - amongst other things by organising a joint conference in which these Leitbilder were presented and discussed - in presenting their initiatives to national authorities, suggesting that the national government should have an integration policy and should support cities in their integration policies. However this latter initiative was not successful: it took several more years before the concept of integration was introduced at the national level in Switzerland.

Whatever the history of local integration policies, a common characteristic during the last decade seems to be that tensions between cities and national governments on a number of issues developed or increased (see e.g. Scholten 2013 for the Dutch case). Such tensions may relate to different views on how to implement (restrictive) immigration policies: how to handle irregular migrants in practice, particularly the ones that cannot be returned to their country of origin? How to implement restrictions on access to facilities and services in the domains of employment, housing, education and health in order to combat illegal residence ${ }^{10}$ Disagreement between national and local authorities may also relate to the new reception policies, the civic integration courses, the increased cultural requirements for continued residence and for naturalisation: where national policies may be quite ideological on such matters, local policy practitioners tend to look more for feasible practical solutions that are acceptable in immigrant communities. Tensions also arise when the financing of integration facilities is at stake, particularly when national policies prescribe new action, but do not deliver the financial and other resources needed to implement it.

Such tensions make it clear that the interests at stake in integration policies and their implementation may differ substantially, or be perceived as different, at the local and national level. At the city level, the confrontation with the day-today consequences of immigration is far more direct, and especially immigrants more immediately feel the implications of policies. European cities are increasingly aware that they need long-term, consistent integration policies in order to preserve their viability as communities and their liveability for all residents. During the last decade, cities have increasingly turned to new partners outside the national arena in their search for knowledge and resources for their policies, as we shall see below.

\subsection{EU Integration Policy and Horizontal Cooperation Between Cities}

Recently European cities have developed significant new relations outside their national context, particularly in the form of networks of cities that exchange knowledge and practical experiences in local integration policies. Although such initiatives primarily aim at cross-national horizontal forms of cooperation between

\footnotetext{
${ }^{10}$ The Linkage Law in the Netherlands, for example, obliges all public service providers to check for legal residence of clients. Illegal clients should not be served.
} 
cities, all of these networks have strong connections with and support from the European Commission. New coalitions have emerged in the multi-level governance of migration and integration in Europe.

This new constellation goes back the Amsterdam Treaty of 1997 and the Tampere Summit of ministers responsible for migration and integration policies in 1999. These had stipulated that asylum and migration should become a common EU policy domain, that existing migration policies and practices should be harmonised, and that third-country nationals who are long-term residents should be granted rights that approximate those of EU-citizens as closely as possible (which was the interpretation of the integration concept at that time).

In the first period of the Tampere Programme (1999-2004), EU policymaking concentrated strongly on the harmonisation of migration and asylum policies; integration was nearly absent (Van Selm and Tsolakis 2004). In fact, until 2003 EU policies started from the implicit assumption that if the legal position of immigrants was made as equal as possible to national citizens (as the Tampere programme stipulated), and if adequate instruments were put in place to combat discrimination, then integration processes could be left to societal forces. Thus, legal integration of TCNs was to be ensured by means of the directives on family reunification and free movement after 5 years on the one hand, and by anti-discrimination directives on the other.

It was only in 2003 that the European Commission came up with a more comprehensive view on integration policies in its Communication on Immigration, Integration and Employment. ${ }^{11}$ This Communication defined integration as 'a two-way process based on reciprocity of rights and obligations of Third-Country Nationals and host societies that foresee the immigrant's full participation' (European Commission 2003). This holistic policy approach targets all dimensions of integration (economic, social and political rights, cultural and religious diversity, citizenship and participation). In November 2004, the Council of Ministers responsible for integration agreed on the Common Basic Principles (CBP) for integration as a first step towards a common framework for a European approach to immigrant integration. $^{12}$

In contrast to EU migration policies, which are governed by communitarian principles (first pillar), EU integration policymaking is on an intergovernmental basis (third pillar). This means that policies have to be decided through consensus of member states and there is no binding legislation and directives. This has two effects on the making of policies. On the one hand, national governments do protect their sovereign right to decide in many domains that are important in the broad

\footnotetext{
${ }^{11}$ EC COM (2003) 336 final.

${ }^{12}$ This shift to a very broad conception of integration, however, did not go together with a broadening of the target group: integration policies are supposed to be for Third-Country Nationals only. Immigrants who are citizens from EU member states are supposed to be integrated by definition. The latter assumption has been criticised recently by local authorities in regions that received many new immigrants from accession states after the enlargements of 2004 and 2007 (Collett 2013).
} 
concept of integration, like social security, education, housing and health. In this sense, EU integration policies are clearly 'soft' policies and limited to what national governments allow them to be. On the other hand, through intergovernmental policymaking national governments may also try to transpose their national policies to the EU-level. Since 2004 some West European countries, for example, have increasingly 'uploaded'13 their cultural integration requirements for new Thirdcountry immigrants to EU-integration policies. What had started in the Netherlands as voluntary toolkit programmes for early reception at the local level in the 1990s became mandatory national civic integration courses in the 2000s, and these gained currency in other EU member states after 2004, including testing and sanctions.

Although this specific mechanism of policymaking and implementation is 'soft' - the method is called the 'open method of coordination' - the European Commission has managed to get agreement on some influential practical tools for concrete action. From 2004 to 2006 the INTI- programme (Integration of ThirdCountry Nationals) financed action and research, followed by two more substantial funds running from 2007 to 2013: firstly the European Integration Fund (EIF), and secondly the European Refugee Fund (ERF), designed especially to compensate states for their efforts regarding the reception and integration of refugees. For the European Commission as a policymaker, these funds are important, since they create direct relations between the EU and local and regional authorities (and their policies) on the one hand, and non-governmental civil society partners at all levels on the other.

It is against this new constellation of the multi-level governance of integration that a new coalition between the European Commission and new networks of European cities came into existence shortly after 2004. That new constellation is also the reason why most of the network initiatives of cities for integration policies though not all of them ${ }^{14}$ - are networks of European cities exclusively. I will describe the four most important networks (and the involvement of research in these initiatives) below.

The first is the CLIP-Network (Cities for Local Integration Policies ${ }^{15}$ ), established as a European Network of cities in 2006 by the Congress of Local and Regional Authorities of the Council of Europe, the City of Stuttgart and Eurofound. ${ }^{16}$ It comprises some 30 European cities. The basic idea of the CLIP-project

\footnotetext{
${ }^{13}$ Hannelore Goeman uses this term in her analysis of the constitution of integration policies at the EU level: Goeman 2012. See also Guild et al. 2009.

${ }^{14}$ The Cities of Migration project (http://citiesofmigration.ca) is an initiative taken by the Canadian Maytree Foundation. It is a project rather than a network. Cities of Migration does not have members. Cities are invited to (mostly virtually) share their experiences and learn from each other. The Cities of Migration project's main instrument is its website. The Cities of Migration project is now supported by a dozen private foundations from Europe, North America and elsewhere.

${ }^{15} \mathrm{http} / / / \mathrm{www}$.eurofound.europa.eu/areas/populationandsociety/clip.htm

${ }^{16}$ The European Foundation for the Improvement of Living and Working Conditions (Eurofound) is a tripartite European Union Agency, whose role is to provide knowledge in the area of social and work-related policies.
} 
is to learn by exchanging knowledge and experience between cities. This is done in a systematic process involving research institutes that collect material on integration policies in the participating cities. Five research institutes of the IMISCOE Network of Excellence ${ }^{17}$ have been engaged to do case studies in each of the cities and to compare these cases. The project is organised as a suite of consecutive modules in which specific aspects of local integration policy are studied empirically and compared systematically. The first module was on housing for immigrants (Bosswick et al. 2007), the second on diversity policies in employment and service provision (Spencer 2008), the third on inter-group relations (LükenKlassen and Heckmann 2010), and the fourth on immigrant entrepreneurship (Rath et al. 2011). Each module generated some 25-30 case studies, one comparative synthesis report ${ }^{18}$ and specific policy briefs. Each module was followed by a conference in which the results were discussed among the cities involved and with a wider interested audience. CLIP was funded from 2006 to 2012 by the European Foundation. The CLIP materials focus strongly on policy practices in particular subdomains of integration policies, enabling analysis of the complete chain from policy formulation to implementation and results, showing the often strong dependence of such policies on the functioning of general institutions at the local and national levels. It also gives important insights into the administrative and bureaucratic mechanisms involved in policymaking and implementation.

The second network is Integrating Cities ${ }^{19}$ a project (also since 2006) carried out by Eurocities, a large network of some 140 major European cities. Integrating Cities can be seen as a policy dialogue between Eurocities and the European Commission. The most important platform for dialogue between cities and the European Commission are the Integrating Cities Conferences (2008-2013 in Rotterdam, Milano, Berlin, London, Amsterdam and Tampere). The network has developed the Eurocities Charter on Integrating Cities as a programme for city governance.

In terms of searching for relevant knowledge, Eurocities has implemented a number of EU-funded projects on local integration as well as initiatives from the Eurocities' Working Group on Migration and Integration. The oldest of these projects was the INTI-Cities project that ran for 18 months during 2007-2009. The project was about 'Benchmarking Integration Governance in European Cities': peer reviews were used to assess integration policies in European cities. By measuring policies against a benchmark of high standards, it aimed at delivering expert-

\footnotetext{
${ }^{17}$ The five institutes involved in CLIP are the European Forum for Migration Studies (EFMS) at the University of Bamberg, the Centre on Migration Policy and Society (COMPAS) at the University of Oxford, the Institute for Migration and Ethnic Studies (IMES) of the University of Amsterdam, the Austrian Academy of Sciences and the Centre for Ethnic and Migration Studies (CEDEM) of the University of Liège.

${ }^{18}$ These case studies are available in the e-library of the European Urban Knowledge Network (EUKN: www.eukn.org) and on the website of the European Foundation (www.eurofound.europa. $\mathrm{eu}$ ). The comparative synthesis reports are published by the Council of Europe and at www. eurofound.europa.eu

${ }^{19}$ www.integratingcities.eu/
} 
validated, comparative knowledge on local practices in twelve cities from nine EU member states. Four dimensions of integration policy were assessed:

1. General governance arrangements in the field of migrant integration;

2. Policies in support of individual migrant empowerment;

3. Structures and effectiveness in administrative cooperation;

4. Policies creating and supporting partnerships with civil society and migrant associations.

The final report (Niessen and Kirchberger 2009) summarises benchmarks and recommendations.

The INTI-project was followed by the DIVE-project that had a different and narrower focus on the promotion of diversity and equality in local policies, examining how cities and municipalities can effectively implement diversity policies in management and employment policies led by principles of equality. The project was co-financed by the European Integration Fund. The project resorted again to the methodology of benchmarking and peer reviewing:

1. A set of four benchmarks with regard to the four key responsibilities of cities in promoting mutual accommodation were designed: municipalities as policymakers, employers, service providers and buyers of goods and services;

2. Empirical research was carried out on local integration policies through peerreviews in four major European cities (Berlin, Rome, Amsterdam and Leeds), involving senior city officials with relevant responsibilities;

3. The benchmark report that resulted from this exercise was shared with actors across Europe. It nurtured the Integrating Cities conferences of Berlin 2009 and London 2010 and contributed to the Cities' charter on the role of local government in the integration of migrants. ${ }^{20}$

The results of the project were published in the report 'Cities Accommodating Diversity' (Moloney and Kirchberger 2010).

The MIXITIES-project (Making integration work in Europe's cities 2010-2012) built on the work developed by the INTI- and DIVE-projects. It aimed to develop peer reviews, structured exchange workshops, and toolkits to support cities in delivering the commitments of the Charter. The project focused on three key areas, namely anti-discrimination policy, diversity competences in public services and introductory courses for newcomers. Peer reviews were held on each of these themes respectively in the cities of Gent, Barcelona and Stockholm in 2011. The project's findings and recommendations were presented at the Integrating Cities conference held in Amsterdam in March 2012.

\footnotetext{
${ }^{20}$ The Integrating Cities Charter, launched in 2010, commits signatories to fully acknowledge the presence of migrants in their roles as policymakers, service providers, employers and buyers of goods and services. By September 2013, 30 European cities have signed the charter, which is complemented by a process of monitoring and peer learning.
} 
The third network is Intercultural Cities, ${ }^{21}$ a joint action of the Council of Europe and the European Commission started in 2008. It emerged from the White Paper on Intercultural Dialogue that the Council of Europe had submitted for the European Year of Intercultural Dialogue in that same year. The concept of the Intercultural City was developed earlier by the British think-tank Comedia. In 2004, Comedia conducted a 2 year research programme in the UK, United States, Australia, New Zealand and Norway entitled 'The Intercultural City: Making the Most of Diversity'. It looked at cultural diversity as a source of innovation, creativity and entrepreneurship and how increased intercultural dialogue, exchange and activity can be the catalyst for such a process (Wood 2009).

The Intercultural Cities strategy is a management strategy that publicly advocates respect for diversity and a pluralistic city identity. The Intercultural Cities Programme was developed and first applied in eleven European pilot cities and has evolved since then. The Programme develops tools such as the Intercultural Cities Index for cities to evaluate and develop their policies. It organises international conferences for cities to exchange experience.

The fourth network is a more specific horizontal cooperation initiative, the European Coalition of Cities Against Racism (ECCAR ${ }^{22}$ ) established in 2004 upon the initiative of UNESCO. The aim of this coalition of cities is to share experiences in order to improve policies to fight racism, discrimination and xenophobia. Since 2008, its annual general conference is the main tool for exchange between cities. In the meantime, 104 municipalities from 22 European countries have joined the network and adopted the 'Ten-Point-Plan of Action'.

These four European networks described above are all networks that have built up some form of organisation and continuity of cooperation. But apart from these, there have been numerous forms of cooperation of cities that have existed only during the period that they have been funded (mostly by EU-funds). Examples are ELCI - European Local Cooperation for Integration $(2010)^{23}$ - an 18-month project funded by the European Integration Fund that aims to promote knowledge and understanding of the valuable role that migrant organisations could play in integration process. Another example is DELI - Diversity in the Economy and Local Integration - financed by the Council of Europe and the EIF. It focuses on migrant-owned small and medium size enterprises in the local economy. If we were to scrutinise the long list of projects funded by the ERF, the EIF and also the ESF (European Social Fund) for material relating to local integration of migrants, we would certainly find many more. The ESF in particular has funded a number of projects on local labour market integration and on entrepreneurship in which (im-)migrants have a significant place.

\footnotetext{
${ }^{21} \mathrm{http}: / / \mathrm{www} . c o e . i n t / \mathrm{t} / \mathrm{dg} 4 /$ cultureheritage/culture/Cities/

${ }^{22} \mathrm{http}: / /$ www.citiesagainstracism.org/ICCAR.6.0.html

${ }^{23} \mathrm{http}: / /$ menedek.hu/
} 


\subsection{Conclusions}

This brief exploration of local research-policy dialogues in European cities and municipalities leads me to the following conclusions and hypotheses for further, more systematic research. The first is that - at first sight - local research-policy dialogues as such are nearly invisible in the international literature, but their existence turns out to be much older and more concrete if we turn to the local and national grey literature and to sources close to the partners involved: i.e. cities and their policymakers (and policy documents) on the one hand, and researchers and their institutes on the other. Obviously, much of what is produced in the context of local research-policy dialogues has to be made with more modest means than what is financed at the national level; it is also published in less well-known outlets, mostly in the local language. As a consequence, it does not reach a wider (international) audience.

Secondly, the above exploration suggests that - at least historically - cities and municipalities are more likely to start integration policies and use research (or any other form of systematic knowledge) to underpin their local policies when they are stimulated and supported to do so by higher level governance. The relatively strong and early development of local research-policy-relations in the Netherlands is clearly related to active national integration policies since the beginning of the 1980s. A comparably favourable situation may also have stimulated cities in Sweden in the 1980s and 1990s to develop local policy-research-dialogues. In terms of the functions of research, the data on Dutch cities suggests that - given the national framing of policies - cities used research primarily for instrumentation of policies in the beginning and monitoring and evaluation thereafter.

While an active integration policy at the national level might thus increase the probability of a local research-policy nexus emerging, the absence of such a national policy does not prevent cities from developing local integration policies. A significant number of European cities did so, often using research and initiating research-policy dialogues. Contrary to Dutch and Swedish cities in the 1980s and 1990s, the case of Swiss cities in the late 1990s suggests that, particularly in the beginning, such (externally commissioned) research did fulfil the function that research normally has in the first phase of a policy cycle, namely in recognising and defining problems and setting the frame for local policies.

The above exploration has thus established the existence of local research-policy dialogues in European cities on a larger scale than was known before and in diverse regions of Europe. The material, however, is still too scant to make substantial statements neither on the frequency of such local dialogues, nor on their continuity over time. As to the latter, I would venture the hypothesis that more continuous forms of local dialogues have developed in those cities in which the interest in integration policies developed simultaneously both in local universities or research institutes and among local politicians and civil servants. Those cities seem, however, to be exceptional. Most local research-policy-dialogues, one may hypothesise, are incidental and short term. 
The relevance of what happens at the other levels of the increasingly multilevel governance of integration in Europe becomes clear after the European Union initiated its own integration policy in 2003. Although the European Commission has a very specific definition of integration and of target groups (which is certainly not always shared by cities), increasingly direct policy cooperation has come into existence between the European Commission and local authorities, bypassing the national governance level. In that new constellation of multi-level governance, an interesting form of research-policy dialogues has mushroomed: networks of European cities that evaluate and share their own practical knowledge, assisted in that process by researchers, and financed by the European Commission. A systematic study of what has been produced in three of these networks, Cities for Local Integration Policies, Integrating Cities and Intercultural Cities, would teach us a lot about local policy-research relations as these have evolved in the last decade, both in terms of the individual cities involved and in terms of their cross-national cooperation.

Open Access This chapter is distributed under the terms of the Creative Commons Attribution Noncommercial License, which permits any noncommercial use, distribution, and reproduction in any medium, provided the original author(s) and source are credited.

\section{References}

Alexander, M. (2003). Host-stranger relations in Rome, Tel Aviv, Paris and Amsterdam: A comparison of local policies toward migrants. $\mathrm{PhD}$ thesis, Universiteit van Amsterdam, Amsterdam.

Alexander, M. (2004). Comparing local policies towards migrants: An analytical framework, a typology and preliminary survey results. In R. Penninx, K. Kraal, M. Martiniello, \& S. Vertovec (Eds.), Citizenship in European cities. Immigrants, local politics and integration policies (pp. 57-84). Aldershot: Ashgate.

Alexander, M. (2007). Cities and labour immigration. Comparing policy responses in Amsterdam, Paris, Rome and Tel Aviv. Aldershot: Ashgate.

Begert, U. (2005). Städteleitbild und migrationspolitische Erfahrungen der stadt Bern. In G. D'Amato \& B. Gerber (Eds.), Herausforderung Integration. Städtische Migrationspolitik in der Schweiz und in Europa (pp. 93-99). Zürich: Seismo Verlag.

Bestuurlijk Overleg Stadsdelen Amsterdam. (1998). Ethnic minorities and local government. Report of the conference'. 22 and 23 January 1998, Bestuurlijk Overleg Stadsdelen, Amsterdam.

Blommaert, J., \& Martiniello, M. (1996). Ethnic mobilisation, multiculturalism and the political process in two Belgian cities: Antwerp and Liège. Innovation, 9(1), 51-73.

Body-Gendrot, S. (2000). The social control of cities? Oxford: Blackwell.

Bommes, M., \& Morawska, E. (2005). International migration research. Constructions, omissions and the promises of interdisciplinarity. Aldershot: Ashgate.

Bosswick, W., Lüken-Klaßen, D., \& Heckmann, F. (2007). Housing and integration of migrants in Europe. Strasbourg: Council of Europe.

Bousetta, H. (2001). Immigration, post-immigration policies and the political mobilisation of ethnic minorities: A comparative case study of Moroccans in four European cities. $\mathrm{PhD}$ dissertation, KUB, Brussels. 
Caponio, T., \& Borkert, M. (2010). The local dimension of migration policymaking. Amsterdam: Amsterdam University Press.

Collett, E. (2013). The integration needs of mobile EU citizens: Impediments and opportunities. Brussels: Migration Policy Institute Europe.

Commissie van Deskundigen. (1998). Amsterdam heeft de wereld in huis. Advies van de commissie van deskundigen Herziening Minderhedenbeleid van de gemeente Amsterdam. Amsterdam: Gemeente Amsterdam.

D'Amato, G., \& Gerber, B. (Eds.). (2005). Herausforderung Integration. Städtische Migrationspolitik in der Schweiz und in Europa. Zürich: Seismo Verlag.

Entzinger, H., \& Scholten, P. (2014). The interplay of knowledge production and policymaking: A comparative analysis of research and policymaking on migrant integration in Germany and the Netherlands. Journal of Comparative Policy Analysis, 18, 1-15.

European Commission. (2003). Communication on immigration, integration and employment, 3 June. EC COM (2003) 336 final.

Favell, A. (1998). Philosophies of integration. Immigration and the idea of citizenship in France and Britain. London: Macmillan.

Fennema, M., \& Tillie, J. (2004). Do immigrant policies matter? Ethnic civic communities and immigrant policies in Amsterdam, Liège and Zurich. In R. Penninx, K. Kraal, M. Martiniello, \& S. Vertovec (Eds.), Citizenship in European cities. Immigrants, local politics and integration policies (pp. 85-106). Aldershot: Ashgate.

Garbaye, R. (2000). Ethnic minorities, cities and institutions: A comparison of the modes of management of ethnic diversity of a French and a British city. In R. Koopmans \& P. Statham (Eds.), Challenging immigration and ethnic relations politics: Comparative European perspectives (pp. 283-311). Oxford: Oxford University Press.

Gesemann, F., \& Roth, R. (Eds.). (2009). Lokale Integrationspolitik in der Einwanderungsgesellschaft - Migration und Integration als Herausforderung von Kommunen. Wiesbaden: VS Verlag für Sozialwissenschaften.

Goeman, H. (2012). Integrating integration. The constitution of a EU policy domain on migrant integration. $\mathrm{PhD}$ thesis, Vrije Universiteit Brussel, Brussel.

Guild, E., Groenendijk, K., \& Carrera, S. (Eds.). (2009). Illiberal liberal states: Immigration, citizenship and integration in the EU. Farnham: Ashgate.

Hammar, T. (2004). Research and politics in Swedish immigration management 1965-1984. In M. Jandl \& I. Stacher (Eds.), Towards a multilateral migration regime. Special anniversary edition dedicated to Jonas Widgren (pp. 11-34). Vienna: ICMPD.

Ireland, P. (1994). The policy challenge of diversity: Immigrant politics in France and Switzerland. Cambridge: Harvard University Press.

Kessler, T. (2005). Das Integrationsleitbild des Kantons Basel-Stadt. In G. D’Amato \& B. Gerber (Eds.), Herausforderung Integration. Städtische Migrationspolitik in der Schweiz und in Europa (pp. 104-111). Zürich: Seismo Verlag.

Lüken-Klassen, D., \& Heckmann, F. (2010). Intercultural policies in European cities. Strasbourg: Council of Europe.

Maussen, M. (2009). Constructing mosques. The governance of Islam in France and the Netherlands. $\mathrm{PhD}$ thesis, University of Amsterdam, AISSR.

Ministerie van Binnenlandse Zaken. (1980). Regeringsreactie op het rapport "Etnische minderheden" van de Wetenschappelijke Raad voor het Regeringsbeleid. Den Haag: Min. van BiZa.

Moloney, Th., \& Kirchberger, A. (2010). Cities accommodating diversity: Findings and recommendations from the peer review project "Diversity and Equality in European Cities". At http:// www.migpolgroup.com/public/docs/171.CitiesAccommodatingDiversity_DIVE_22.02.10.pdf

Moore, D. (2001). Ethnicité et Politique de la Ville en France et en Grande-Bretagne. Paris: L'Harmattan.

Moore, D. (2004). In R. Penninx, K. Kraal, M. Martiniello, \& S. Vertovec (Eds.), Citizenship in European cities. Immigrants, local politics and integration policies (pp. 127-138). Aldershot: Ashgate. 
Musterd, S., Ostendorf, W., \& Breebaart, M. (1998). Multi-ethnic metropolis: Patterns and policies. Amsterdam: Kluwer Academic Publishers.

Niessen, J., \& Kirchberger, A. (2009). Strategic thinking on equality and mobility. INTI-cities: Key findings and recommendations for European-level policy makers. At: http://www.archive. migpolgroup.com/public/docs/150.INTI-Cities_MPG_Presentation_BenchmarkingReport_28. 01.09.pdf

Penninx, R. (1988). Wie betaalt, bepaalt? De ontwikkeling en programmering van onderzoek naar migranten, etnische minderheden en woonwagenbewoners 1955-1985. Amsterdam: SGI-reeks.

Penninx, R. (2005a). Integration of migrants: Economic, social, cultural and political dimensions. In M. Macura, A. L. MacDonald, \& W. Haug (Eds.), The new demographic regime: Population challenges and policy responses (pp. 137-152). New York/Geneva: United Nations.

Penninx, R. (2005b). 'Integratiebeleid in Angers, Haarlem en Osnabrück: visies, strategieën en de praktijk' (pp. 9-16), 'Integrationspolitik in Angers, Haarlem en Osnabrück: Ansichten, Strategien und Praxis' (pp. 43-52), 'Politique d'integration à Angers, Haarlem en Osnabrück: points de vue, stratégies et pratique' (pp. 77-86). In Multiculturalité et Integration à Angers, Haarlem et Osnabrück, Multiculturaliteit en Integratie in Angers, Haarlem et Osnabrück, Multiculturalität und Integration in Angers, Haarlem et Osnabrück, Haarlem: Gemeente Haarlem. Also published on: http://www.eukn.org/netherlands/themes/Urban_Policy/Social_ inclusion_and_integration/Integration_of_social_groups/multiculturality-in-angers-haarlemand-osnabruck_1024.html

Penninx, R. (2009). Vergleichende Studien zu Integrationspolitiken europäischer Städte. In F. Gesemann \& R. Roth (Eds.), Lokale Integrationspolitik in der Einwanderungsgesellschaft Migration und Integration als Herausforderung von Kommunen (pp. 611-634). Wiesbaden: VS Verlag für Sozialwissenschaften.

Penninx, R., Kraal, K., Martiniello, M., \& Vertovec, S. (Eds.). (2004). Citizenship in European cities. Immigrants, local politics and integration policies. Aldershot: Ashgate.

Penninx, R., Berger, M., \& Kraal, K. (Eds.). (2006). The dynamics of international migration and settlement in Europe. A state of the art. Amsterdam: Amsterdam University Press.

Rath, J., Penninx, R., Groenendijk, K., \& Meyer, A. (2001). Western Europe and its Islam. Leiden/Boston/Cologne: Brill.

Rath, J., Swagerman, A., Krieger, H., Ludwinek, A., \& Pickering, L. (2011). Promoting ethnic entrepreneurship in European cities. At: http://www.eurofound.europa.eu/publications/ htmlfiles/ef1138.htm

Rex, J., \& Samad, Y. (1996). Multiculturalism and political integration in Birmingham and Bradford. Innovation, 9(1), 11-31.

Rogers, A., \& Tillie, J. (Eds.). (2001). Multicultural policies and modes of citizenship in European cities. Aldershot: Ashgate.

Scholten, P. (2013). Agenda dynamics and the multi-level governance of migrant integration: The case of Dutch migrant integration policies. Policy Sciences, 46, 217-236.

Slootman, M., \& Tillie, J. (2006). Processes of radicalisation - Why some Amsterdam Muslims become radicals. Amsterdam: Institute for Migration and Ethnic Studies.

Spencer, S. (2008). Equality and diversity in jobs and services: City policies for migrants in Europe. Strasbourg: Council of Europe.

Thränhardt, D., \& Bommes, M. (Eds.). (2010). National paradigms of migration research. Göttingen: V\&R Unipress.

Tremp, J. (2005). Vom Integrationsleitbild zur Integrationspolitik der stadt Zürich. In G. D’Amato \& B. Gerber (Eds.), Herausforderung Integration. Städtische Migrationspolitik in der Schweiz und in Europa (pp. 87-92). Zürich: Seismo Verlag.

Uniken Venema, P. (1986). Overzicht gemeentelijk minderhedenonderzoek. Leiden: ACOM.

Van Selm, J., \& Tsolakis, E. (2004). The enlargement of an 'area of freedom, security and justice': Managing migration in a European Union of 25 members. Policy Brief, May 2004. Washington: Migration Policy Institute.

Wicker, H.-R. (2003). Einleitung: Migration, Migrationspolitik und Migrationsforschung. In H.-R. Wicker, W. Haug, \& R. Fibbi (Eds.), Migration und die Schweiz (pp. 12-62). Zürich: Seismo. 
Wolff, R., Van Heelsum, A., \& Penninx, R. (1999). Erkend, aangesproken, aanspreekbaar? Evaluatie van het migrantenbeleid van voormalig stadsdeel Oost en de participatie van organisaties van migranten, 1996-1998. Amsterdam: Stadsdeel Oost/Watergraafsmeer.

Wood, P. (Ed.). (2009). Intercultural cities: Towards a model for intercultural integration. Strasbourg: Council of Europe Publishing. Also available at http://www.coe.int/t/dg4/ cultureheritage/culture/cities/ICCModelPubl_en.pdf

Zincone, G., Borkert, M., \& Penninx, R. (Eds.). (2011). Migration policymaking in Europe: The dynamics of actors and contexts in past and present (IMISCOE Research series). Amsterdam: Amsterdam University Press. 